\title{
Ontogenetic changes in food intake and digestion rate of the herbivorous marine iguana (Amblyrhynchus cristatus, Bell)
}

\author{
M. Wikelski ${ }^{1}$, B. Gall ${ }^{2}$, F. Trillmich ${ }^{3}$ \\ ${ }^{1}$ Max-Planck-Institut, Abt. Wickler, W-8130 Seewiesen, Post Starnberg, Germany \\ 2 Botanical Institut, Abt. Scheer, Menzingerstrasse 67, W-8000 München 19, Germany \\ ${ }^{3}$ Department of Behavioural Ecology, P.O. Box 100131, W-4800 Bielefeld 1, Germany
}

Received: 26 October 1992/ Accepted: 18 February 1993

\begin{abstract}
Young reptiles have higher relative energy demands than adults, but the proposed ontogenetic changes in diet to fulfil these demands were not found in the algae-eating Galápagos marine iguanas on Santa Fé. Feeding and digestion rates were investigated to analyse how young achieve higher energy intake. Daily food intake of free ranging marine iguana hatchlings (6-11 months old) was about one third that of adults, but relative intake ( $\mathrm{g}$ dry mass $\cdot \mathrm{g}^{-1}$ wet mass $\cdot$ day $^{-1}$ ) was four times higher in the hatchlings. During feeding experiments, relative daily food intake of hatchling marine iguanas was approximately three times higher than that of adults $\left(0.042\right.$ vs $0.013 \mathrm{~g}$ dry mass $\cdot \mathrm{g}^{-0.8}$ wet mass day $^{-1}$ ), and mean gut passage time was two times shorter ( 5 vs 10 days). The hatchlings also maintained high body temperatures $\left(36.7^{\circ} \mathrm{C}\right)$ even under relatively cool daytime air temperatures of $32^{\circ} \mathrm{C}$. Apparent digestibility of algal food measured both during feeding trials and by $\mathrm{Mn}^{2+}$ AAS (atomic absorption spectrometry) for freeranging iguanas was $70 \%$, independent of body size and temperature. The red algae prevailing in the diet were high in protein ( $30 \%$ dry mass) and energy $(12.1 \mathrm{~kJ} / \mathrm{g}$ dry mass). Diving iguanas had higher rates of energy intake than intertidal foragers, but daily intake was less. Maintenance of high body temperature enabled hatchlings to achieve high digestion rates and, combined with high relative intake, thus achieve sufficient energy intake for rapid growth despite higher mass specific metabolic rates. Estimates of biomass of marine iguanas and their algal food are given for a section of coastline on Santa Fé.
\end{abstract}

Key words: Ontogeny - Herbivory - Food intake - Digestion - Marine iguana
Plant material is difficult to digest due to its strong cell walls and high content of indigestible fibre (McBee 1971; Troyer 1984a, b, c). Despite these difficulties, reptiles apparently digest plant material with an efficiency previously attributed only to ruminants (Hungate 1966; Janis 1976; Nagy 1977; Bjorndal 1979; Troyer 1984b, c). Most, if not all, herbivorous reptiles use a microbial hindgut fermentation system (Troyer 1984a, b; Foley et al. 1992) that may work as effectively as the mammalian one.

Nevertheless, problems of energy and nutrient acquisition from plant material are very real, because digestion takes time. More time is needed as plant fibre content increases (Hungate 1966; Langer and Snipes 1991). This constraint applies most strongly to small herbivorous reptiles and the young of larger herbivorous species, since the mass specific energy expenditure of small animals is higher than that of large adults : reptilian mass specific metabolic rate is proportional to mass to the 0.8 th power (Nagy 1982).

Consequently, the diet choice of hatchlings of many herbivorous reptiles (e.g. the green iguana) differs from that of adults. Young use food which is higher in protein content and thus yields more nutrients, even if the fibre content of the food is higher (Troyer 1984b). Pough (1973) suggested that lizards weighing less than 50-300 g must feed on insects to cover their energy demand and hypothesized that this is also true for hatchlings of the larger herbivorous species. Even though this relationship between body size and diet in lizards cannot hold true generally (see Troyer 1984b), it nicely focuses the problems faced by small herbivorous lizards.

This problem is also encountered by juvenile marine iguanas. Marine iguanas are endemic to the Galápagos archipelago and, unique among lizards, they feed upon macrophytic marine algae (Darwin 1883; Hobson 1965, 1969; Carpenter 1966). Most marine iguanas feed on intertidal rocks which are only exposed at low tide. Adult animals above threshold weights can also exploit the rich subtidal algae grounds (mostly between 3 and $5 \mathrm{~m}$ depth) by diving (Darwin 1883; Carpenter 1966; Hobson 1969; 

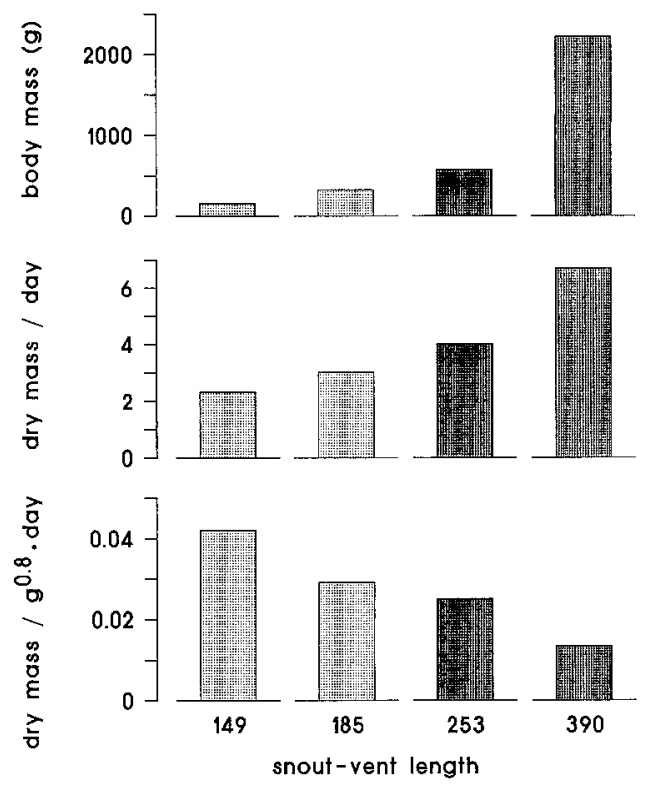

Fig. 1. Body mass and intake of algal dry mass relative to body mass during the feeding experiments. The lowest section of the graph shows the intake of algae by relative metabolic mass (energy expenditure scales to the 0.8 th power of body mass, Nagy 1982)

Trillmich and Trillmich 1986). Marine iguanas hatch at a body mass of approximately $50 \mathrm{~g}$ and, depending upon the island, grow to a final body mass of between 1 and $12 \mathrm{~kg}$, a roughly 100 -fold increase in body mass (Trillmich and Trillmich 1984). The mass specific energy consumption $\left(\mathrm{kJ} \mathrm{g}^{-1} \mathrm{day}^{-1}\right.$ ) of a $70 \mathrm{~g}$ hatchling is twice as high as that of a $2000 \mathrm{~g}$ adult (Nagy 1982); over and above this maintenance requirement, young marine iguanas must garner the energy for rapid growth. But how do they do it?

To overcome the problems encountered when relying on a diet which is difficult to obtain and digest, and which can only be harvested during the short time period around low tide, small marine iguanas could (following Troyer 1984b) (i) choose a diet of higher quality than adults, as yearling green iguanas do, (ii) increase their relative food intake during the time-constrained foraging period, (iii) achieve higher digestive efficiencies compared to adults, or (iv) digest the food faster than adults, e.g. by maintaining higher body temperatures during digestion.

To test these hypotheses, we investigated age- and sizecorrelated changes in diet, daily food intake, digestive efficiency and gut passage time of marine iguanas on Galápagos and related these to the animals' foraging strategy.

\section{Materials and methods}

\section{Study area}

Field work was carried out from October 1989 to March 1990 at Miedo, on the SE coast of Santa Fé, an uninhabited, arid island covering 2400 ha. Marine iguanas had been permanently and in- dividually marked as adults or shortly after hatching in previous years (Laurie 1990). Iguanas on Santa Fé hatch in April and May and the youngest cohort in our study, here called "hatchlings", consequently was between 6 and 11 months old.

Animals were captured by gripping their tails or by noosing. Snout to vent length (SVL) was measured and body mass determined with spring balances (Pesola). Deep body temperatures $\left(T_{\mathrm{B}}\right)$ were measured cloacally to the nearest $0.2^{\circ} \mathrm{C}$ by inserting an electronic thermometer (testotherm, "mini-class" 1100, Lenzkirch, Germany) to a depth of approximately $2 \mathrm{~cm}$.

The intertidal area was classified into upper and lower intertidal according to the abundance of red algae growth on barnacles (no red algae on barnacles in upper, many in lower intertidal). Three approximately $7-\mathrm{m}$ transects from the uppermost intertidal zone down to the low tide waterline were made on 29 January 1990 , exactly following the intertidal topography. At each centimetre the presence or absence and genus of algae were recorded. Composition and percentage of algal cover were determined. Ambient temperature on the upper and lower intertidal surface was measured with thermocouples every 3 min on 11 January 1990 , from 8.00 a.m. to 11.00 a.m. (low tide at 8.50 a.m.). Waves washing over the thermocouples were counted from prominent rocks.

\section{Food intake and food processing}

Forty-eight marked animals were observed (focal animal sampling, Altman 1974) for 28 days in December 1989 and January 1990. The daily observation period included all the time available for sub- and intertidal foraging, so the entire foraging activity of each iguana was recorded. Animals were captured within $5 \mathrm{~min}$ after terminating the last foraging trip on a given day. The end of foraging could easily be determined by the fact that the animals retreated to high basking spots (Trillmich and Trillmich 1986). Iguanas were then measured and weighed with an electronic balance (Sartorius) to the nearest $0.5 \mathrm{~g}$ and their stomachs flushed (Wikelski 1991). Animals up to $150 \mathrm{~mm}$ SVL were stomach lavaged with about $150 \mathrm{ml}$ seawater, and adults lavaged with up to $500 \mathrm{ml}$. The samples were immediately fixed in $4 \%$ formaldehyde. The algal composition in the stomach lavages of 17 animals was determined by sorting the algal blades according to genus (immediately after lavage). Health and survival of those animals was not affected: they fed normally the following days and many of them were resighted in the 1992 field season. From 19 marked iguanas of known size seen defaecating, fresh faeces were collected (once per animal) and sun-dried.

In March 1990 two experiments were run on four animals each, to determine the duration of food passage and digestive efficiency. Marine iguanas were put into enclosures made of plastic foil inside a wire mesh cage. One experiment took place in the open sun with a wooden shelter providing shade in part of the enclosure, the second in the shade of an open tent shading the entire enclosure. Five times a day $(0700,1000,1300,1500$, and 1800 hours) the ambient temperature $3 \mathrm{~cm}$ above the ground was measured and faeces (if present) collected and dried. Three times a day (1000, 1300 , and 1500 hours) $T_{\mathrm{B}}$ of the experimental animals were measured. Before feeding, the animals were weighed to the nearest $0.5 \mathrm{~g}$. They were then force-fed once a day at low tide with algae freshly collected from their intertidal foraging area. Seawater was gently pressed out of the algal food, food samples were weighed, and subsamples put aside and fixed in $4 \%$ formalin for chemical and dry weight analysis. The dry to wet weight conversion factor was 4.35 (water content of algae: $77 \%$ ). Genus composition of experimental food was similar to algal samples from stomach contents of freeranging animals. Algal blades were cut to lengths normally occurring in stomach contents (approximately 3-5 mm). Animals were fed sufficient algae to maintain constant body mass during the experimental period and no more algae were fed then lavaged out of the stomachs of similarly sized free-ranging iguanas. Apparent digestibility, an overall estimate of digestive efficiency, was defined as the mass ratio of food retained (food consumed minus faeces produced) to the food consumed (Troyer 1984b). 
Mean gut passage time was determined for each iguana by mixing 10 coloured glass beads (diameter $1.5 \mathrm{~mm}$ ) and 10 plastic tags $(3 \times 3 \mathrm{~mm})$ with every meal. We assumed that the markers moved at the same rate as the food (Troyer 1984b; for a critical evaluation see Zimmermann and Tracy 1989). This appears to be a valid assumption since a few large brown algal blades (which remained nearly undigested) also moved through the gut at the same rate. Mean gut passage time was defined as the average number of days for $50 \%$ of each day's beads or tags to appear in the faeces (Fig. 2). Both tags and beads moved through the gut at the same rate. Animals were kept until gut passage time was determined (7-13 days).

\section{Chemical analyses}

Formalin-fixated stomach samples and dried faeces were lyophilized, homogenized in liquid nitrogen and lyophilized again. To determine protein digestibility, nitrogen contents were determined by the standard micro-Kjeldahl method and protein- $\mathrm{N}$ after precipitation of proteins with trichloroacetic acid. The energy content of stomach samples and faeces was determined by bomb calorimetry. The ash content as determined by calorimetry was subtracted from the dry weight of the original sample. Manganese content of stomach contents and faeces was determined (after aqua regia disintegration) by standard atomic absorption spectrometry (AAS), both by graphite-furnace AAS and by induced coupled plasma.

\section{Results}

\section{Diet}

Marine iguanas of all sizes fed almost exclusively on marine algae. Other items commonly flushed out of the stomachs of 48 animals were small stones (cf. Eibl-Eibesfeldt 1964; Carpenter 1966) up to a size of $6 \mathrm{~mm}$ diameter in adults, and invertebrates in very small quantities (no more than occur in algae). Marine iguanas were also rarely seen to feed on faeces of conspecifics and sea lions.

Red algae grew more densely in the lower than in the upper intertidal zone (surface cover along the transects $95.6 \%$ vs $13.9 \%$ respectively). In the upper intertidal zone, wave washing was reduced $\left(0.7 \pm 0.14\right.$ times $\min ^{-1}$ vs $1.9 \pm 0.52$ times $\mathrm{min}^{-1}$ in the lower intertidal zone) and surface temperatures were higher (mean temperature during low tide $26.4 \pm 2.3^{\circ} \mathrm{C}$ vs $23.1 \pm 1.3^{\circ} \mathrm{C}$ in the lower intertidal zone at a sea surface temperature of $21^{\circ} \mathrm{C}$ ). Green and brown algae each covered less than $1 \%$ of the intertidal foraging area. These algae contributed less than $0.1 \%$ of the dry mass in the 17 stomach lavages. Genus composition in stomach contents was similar in all size classes of intertidally foraging animals, with only subtidally foraging marine iguanas showing a different diet composition (Table 1).

The dietary algae of marine iguanas were high in protein $(30 \pm 1.4 \%, n=4$, protein in dry mass estimated from total $\mathrm{N} ; 27.5 \pm 1.7 \%, n=4$, protein determined from protein- $\mathrm{N}$ in dry mass). Of the dry mass in stomach contents, protein contributed $23.3 \pm 2.35 \%, n=31$ $(17.4 \pm 2.5 \%$ protein after precipitation, $n=31)$, whereas in the faecal dry mass it was $20.27 \pm 4.2 \%, n=19$ $(15.4 \pm 0.5 \%$ protein after precipitation, $n=19)$. Stomach contents and faeces of hatchling marine iguanas had the same protein content as those of larger animals (MannWhitney U-test, $n_{1}=8, n_{2}=23, P>0.05$ ) and there was no difference in protein content in the stomach contents of sub- versus intertidally feeding animals (Mann-Whitney $\mathrm{U}$-test, $n_{1}=5, n_{2}=18, P>0.05$ ).

\section{Energetics and food intake in different areas}

High variation in daily food intake occurred because marine iguana feeding times varied daily according to low tide, and because animals fed in different intertidal areas. Animals that fed longer and in more productive foraging areas (lower intertidal) had higher algal intake per day (multiple regression model $r^{2}=73 \%, F=18.1$, $P<0.001$; for the parameters body mass: $P<0.01$; foraging time: $P<0.001$; and intertidal area: $P<0.05$ ).

Among large, free-ranging males, intake per day was lower in subtidal than in intertidal foraging areas (Table 2; Mann-Whitney U-test, $n_{1}=5, n_{2}=6, P<0.01$ ). This difference cannot be attributed to differences in body mass between the two male categories (MannWhitney U-test, $\left.n_{1}=5, n_{2}=6, P>0.05\right)$. However, intake of algae per unit feeding time was higher in the subtidal area than in the intertidal area (Table 2; Mann-Whitney U-test, $n_{1}=5, n_{2}=6, P<0.01$ ).

The energetic value of stomach samples was $10.4 \pm 2.0$ $\mathrm{kJ} / \mathrm{g}$ dry mass, that of faeces $10.5 \pm 1.2 \mathrm{~kJ} / \mathrm{g}$, and that of algal food $12.1 \pm 2.4 \mathrm{~kJ} / \mathrm{g}(n=8,18$, and 6 respectively). Algal food from stomach samples of hatchlings and adults did not differ in caloric content (Kruskal Wallis test, $P=0.44$ ).

Table 1. Diet composition (\% dry weight in stomach contents) of free-ranging marine iguanas of different sizes or foraging modes (Dictyota: Phaeophyta, Brown algae; Centroceras, Gelidium, Gracilaria, Lithothamnium, Pterocladia: Rhodophyta, Red algae)

\begin{tabular}{llllcr}
\hline $\begin{array}{l}\text { Feeding area } \\
\text { Diet }\end{array}$ & $\begin{array}{l}\text { Males }(n=5) \\
\text { Subtidal }\end{array}$ & $\begin{array}{l}\text { Males }(n=5) \\
\text { Intertidal }\end{array}$ & $\begin{array}{l}\text { Juvenile }(n=4) \\
\text { Intertidal }\end{array}$ & $\begin{array}{l}\text { Hatchling }(n=3) \\
\text { Intertidal }\end{array}$ & $\begin{array}{l}\text { Overall mean for } \\
\text { intertidal foragers }\end{array}$ \\
\hline Gelidium sp. & $91.6 \pm 1.6$ & $12.6 \pm 6.4$ & $7.6 \pm 3.3$ & $7.7 \pm 2.4$ & $9.7 \pm 4.4$ \\
Centroceras sp. & - & $85.0 \pm 6.1$ & $90.5 \pm 5.4$ & $86.4 \pm 4.2$ & $87.2 \pm 5.4$ \\
$\begin{array}{l}\text { Dictyota } \text { sp. } \\
\text { Pterocladia } \text { sp. }\end{array}$ & $2.3 \pm 1.8$ & $2.5 \pm 0.6$ & $1.2 \pm 0.4$ & - & $1.4 \pm 0.5$ \\
Gracilaria sp. & $1.6 \pm 0.5$ & - & - & - & - \\
Phaeophyta & $2.5 \pm 1.3$ & - & - & - & $0.2 \pm 2.2$ \\
Lithothamnium sp. & $0.6 \pm 0.1$ & $0.4 \pm 6.1$ & - & $5.9 \pm 2.9$ & $1.5 \pm 1.3$ \\
\hline
\end{tabular}


Table 2. Food intake of free-ranging marine iguanas determined by stomach flushing

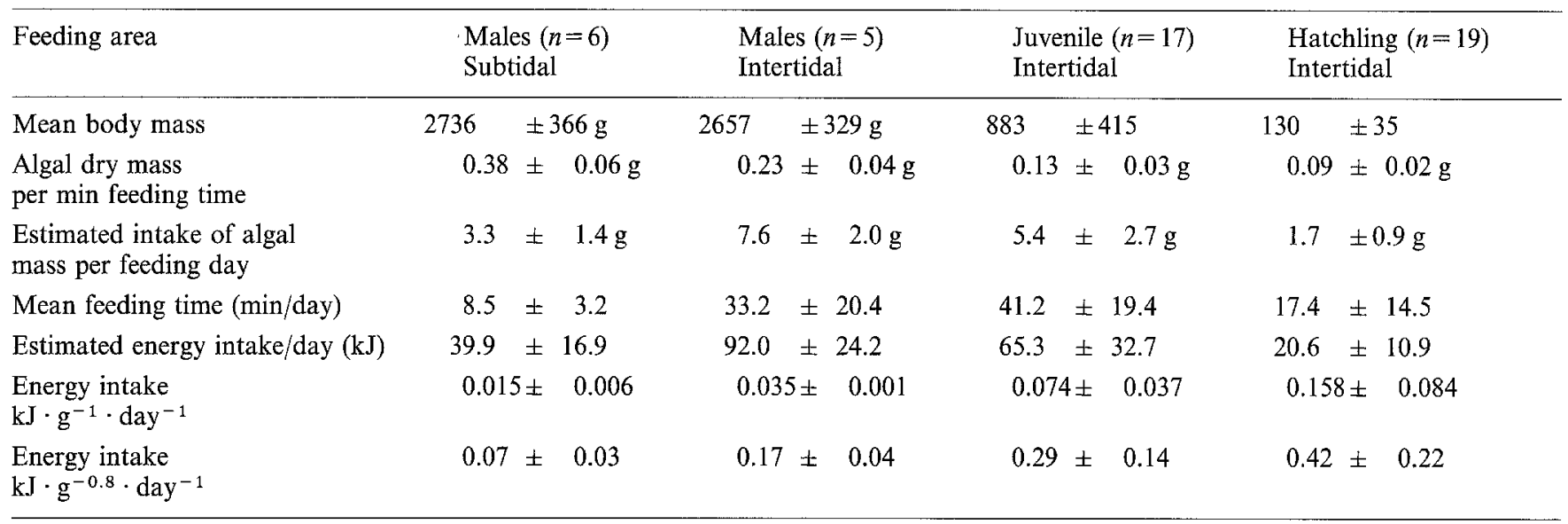

Table 3. Results of two feeding experiments under two thermal conditions (entirely shaded vs open sun available) for different-sized marine iguanas (see Materials and methods for details). Apparent digestibility was determined for each day, and gut passage timed for each set of marker beads; both were averaged over the experimental period. $T_{\mathrm{B}}$, deep body temperature; $\mathrm{SD}$, standard deviation

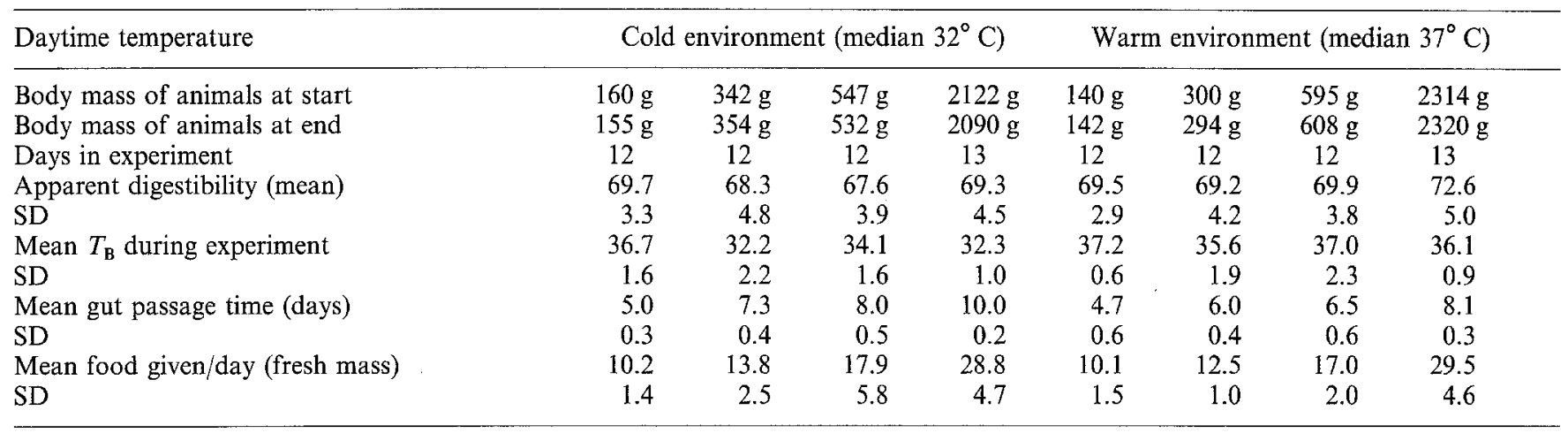

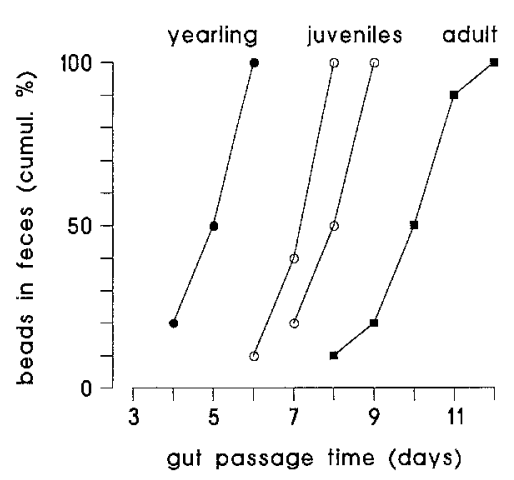

Fig. 2. Mean gut passage time (see text and Table 3) of four marine iguanas under conditions of the "cool environment" experimental treatment; $100 \%$ beads in faeces equals 10 beads

\section{Feeding experiments and digestive efficiency}

In the feeding experiment under the shade $\left(32^{\circ} \mathrm{C}\right.$ median daytime air temperature) the hatchling marine iguana was the only animal that maintained high daytime $T_{\mathbf{B}}$ Table 3. The $T_{\mathbf{B}}$ of older/larger iguanas was lower under these "cold" experimental conditions. To maintain body mass during the feeding experiments, small animals needed a higher mass specific intake of algal dry mass per day than large animals (Friedman test, $\chi_{r}^{2}=11.7, d f=3$, $P<0.01)$ Fig. 1, Table 3. Smaller animals had shorter gut passage times under both temperature regimes (Fig. 2, Table 3). The beads fed with the algal food on a given day appeared in the faeces quite synchronously: \pm 1 day in the hatchling and the two juveniles and \pm 2 days in the adult (Fig. 2).

Irrespective of size, all experimentally fed animals had similar digestive efficiencies (Table 3 ). Faecal dry mass accounted for $30.4 \%$ of the ingested algal dry mass $(\mathrm{SD}=1.6 \%, n=8)$ and there was no significant variation among the four animals in an experiment (Friedman test, $\chi_{r}^{2}=8.2, d f=3, P>0.05$ ) Table 3 . To measure digestive efficiency of free-ranging animals we determined the $\mathrm{Mn}^{2+}$ concentrations in stomach contents $(=$ fresh algae) and in faeces. Since $\mathrm{Mn}^{2+}$ is not taken up by the gut (Nagy 1982), its concentration is higher in faeces and the increase in concentration is a measure of digestive efficiency. The stomach contents of free-ranging marine iguanas contained $10.32 \pm 5.07 \quad(n=14)$, the faeces $34.48 \pm 15.24 \mu \mathrm{g}$ manganese/g dry weight $(n=9) ; 10.32 \mu \mathrm{g}$ manganese equals $29.93 \%$ of $34.48 \mu \mathrm{g}$ manganese, thus marine iguanas had digestive efficiencies of $70.07 \%$ (cf. Nagy and Shoemaker 1984). 


\section{Biomass estimations}

Using our results, we can estimate the food consumption of the marine iguana population at a peninsula of our study site: 751 marine iguanas of known ages and/or sizes, feeding upon a $521 \mathrm{~m}^{2}$ intertidal area, consumed $1.77 \mathrm{~kg}$ of algal dry mass per day or $638 \mathrm{~kg}$ per year, corresponding to approximately $2774 \mathrm{~kg}$ fresh algal mass per year (cf. Nagy and Shoemaker 1984). One square metre of intertidal area therefore produced at least $3.4 \mathrm{~g}$ dry mass (14.8 g wet mass) of food-algae per day. The entire marine iguana population of our study site (shoreline about $1 \mathrm{~km}, 450$ hatchlings, 2100 juveniles, 3000 adults; Dellinger, personal communication) consumed an estimated $41600 \mathrm{~kg}$ algal fresh mass per year.

\section{Discussion}

Large lizards can meet their energy demands more easily than small ones (Zimmermann and Tracy 1989), because the mass specific energy expenditure of an adult marine iguana $\left(\mathrm{kJ} \cdot \mathrm{g}^{\text {body mass }}{ }^{-1}\right)$ is about half that of a hatchling when estimated by the equation developed by Nagy (1982) for field metabolic rates. Thus the early ontogenetic stages need a relatively larger energy budget. In the following, we first discuss our findings and then ask how hatchlings achieve their requirements.

\section{Energetics}

To fulfil their energy demands, free-ranging hatchlings ingested about four times more algae relative to body mass than adults $\left(\mathrm{kJ} \cdot \mathrm{g}^{-1} \cdot \mathrm{day}^{-1}\right.$, Table 2$)$, which was more than expected from field metabolic equations (Nagy 1982). These data were supported by the results of the feeding trials, in which hatchlings needed twice to three times more food per day and per gram of body mass to maintain body mass (Table 3, Fig. 1). The marine iguanas were not overfed in our feeding trials, as Zimmermann and Tracy (1989) maintain happened in the experiments of Harlow et al. (1976), since in ours they were only given enough food to maintain body mass. Differences in body temperature between the two experiments were small enough $\left(\max .3 .8^{\circ} \mathrm{C}\right)$ to ensure that the animals did not experience major differences in energy expenditure.

\section{Diet choice}

Both green (Troyer 1984a-c) and marine iguanas (this study) are herbivorous throughout life, excluding the option of ingesting high quality protein (e.g. insect) food. If young animals chose a plant diet of higher quality, we would expect higher protein contents in their stomachs than in those of adults. No differences in diet and its quality were found between adult and juvenile marine iguanas (Table 1), in contrast to green iguanas. If diving marine iguanas chose a higher quality diet, again higher protein concentrations in the stomachs of subtidally versus intertidally feeding animals would be expected. This was not the case, but diving marine iguanas achieved higher intake rates ( $\mathrm{g}$ dry mass/feeding time, Table 2 ) during subtidal foraging. In addition, they were able to forage at times when intertidal foraging was impossible, i.e. high tide (Trillmich and Trillmich 1986). Marine iguanas on Santa Fé never fed exclusively by diving, presumably because rapid cooling during immersion in cold seawater constrained their foraging abilities (Wikelski 1991). Thus for the relatively small diving marine iguanas of Santa Fé island (approximately $2500 \mathrm{~g}$ ) subtidal foraging only provides additional food, whereas for larger animals on other islands (e.g. Fernandina: Trillmich and Trillmich 1986) subtidal feeding provides sufficient energy to allow large animals to adopt this foraging strategy exclusively.

Marine iguanas also fed on faeces of conspecifics. Although the amount ingested was negligible, this may serve to take up symbionts (cf. Troyer 1984a), a consequence not yet documented for marine iguanas. Whether sealion faeces provide any important nutrients cannot be judged at present.

\section{Digestive physiology}

Small marine iguanas use strategies other than diet choice to meet the high energy requirements of a fastgrowing animal. They speed up digestion by maintaining higher daytime body temperatures (Table 3; Wikelski 1991). Compared to other herbivorous reptiles of similar size (cf. Zimmermann and Tracy 1989), mean gut passage time was high in marine iguanas and about twice the time measured for green iguanas (Troyer 1984b). Gut passage time decreased with higher body temperatures (Table 3 ), as found in other herbivorous reptiles (cf. Windell and Sarokon 1976; Harwood 1979; Waldschmidt et al. 1986, 1987; Van Damme et al. 1991).

Apparent digestibility was high in experimental and free-ranging marine iguanas $(70 \%)$ compared to other herbivorous reptiles (cf. Zimmermann and Tracy 1989), and similar to green iguanas (Troyer 1987). No difference was found between small and large marine iguanas. Digestive efficiency was not affected by body temperature, and thus by speed of digestion. Similar findings were obtained by Zimmermann and Tracy (1989) found in desert iguanas (Dipsosaurus dorsalis), but in contrast to the findings of Harlow et al. (1976) in the same species (see Zimmermann and Tracy 1989 for discussion), and to green iguanas (Troyer 1987). Although hatchlings spent less time digesting their food, they extracted as much protein (or cell contents) as adult animals did. The digestive efficiency of marine iguanas on Fernandina island (Nagy and Shoemaker 1984) was the same as on Santa Fé, although the diet of the former consists to $95 \%$ of green algae and animals are twice as large as on Santa Fé. 
How do hatchlings achieve their requirements?

Troyer (1984b) suggested four hypotheses (i-iv) as to how hatchling green iguanas could potentially satisfy their higher nutrient requirements relative to adults. We did not test whether (i) the relative gut capacity was higher in hatchlings, because no dead animals were found during our study period. Following Troyer's results (1984b) on green iguanas, we assumed that hatchling and adult marine iguanas have similar relative digestive tract size. There was no evidence for (ii) choice of better diet quality in hatchlings because animals of all sizes had similar algae genus composition in their stomachs. Small animals did not, as we had expected, use diet with a higher protein content providing more nutrients. Small animals could additionally (iii) increase digestive efficiency, but this is found neither in green nor in marine iguanas (Troyer 1984c). However, (iv) gut passage time is lower in hatchlings than in larger marine iguanas without reduced protein digestibility. By processing food faster smaller animals increased the amount of nutrients absorbed per unit time. A decrease in passage time with decreasing body size seems to be a common feature of herbivores, as smaller species of antelope also have higher fermentation rates than larger species (Hungate 1966).

To make efficient use of faster digestion small marine iguanas must achieve a higher food intake. This they do by using a more active foraging mode than adults: young animals allocate more time per day to foraging and during foraging they shuttle frequently between warm basking and cold foraging places. This enables them to optimally use the short low tide foraging period (Wikelski 1991; Wikelski and Trillmich, in preparation).

To exploit the environment in a most efficient way, marine iguanas use behavioural responses. They select different body temperatures at different ontogenetic stages (Wikelski 1991) to fulfil the specific requirements of their age (for life history trajectories of growth and body condition, see Laurie and Brown 1990a, b). Thus thermoregulation not only affects locomotion or physiology of marine iguanas, but also - at a more integrated level - individual ontogentic development and growth (cf. Huey 1982; Waldschmidt et al. 1987).

Acknowledgements. Without the field assistance of V. Carillo, W. Revelo, S. Layer, H. Eckl, R. Meier, A. Mejia, D. Zanipatin and Y. Torres this work would not have been possible. H. Hartl, Chemistry Department of the University of Munich, provided the AAS analyses. We thank M. Hau, D. Audet, G. v. Hegel, H. Hofer, A. Laurie, F. Walsh, P. Whealan, T. Dellinger, R. Diesel and T. Meijer for discussions and comments on the manuscript, B. Knauer for preparing the figures, J. Dean for his help with the English, P. Bergen and K. Eickhoff for typing the manuscript, and R. Klein for help in obtaining the relevant literature. Special thanks are due to Prof. W. Wickler for his continuous support and the Seewiesen administration for their straightforwardness. The "Wicklercoffee" round provided helpful discussions. This is contribution no. 493 of the Charles Darwin Foundation.

\section{References}

Altman J (1974) Observational study of behavior: sampling methods. Behaviour 49:227-267
Bjorndal K (1979) Cellulose digestion and volatile fatty acid production in the green turtle, Chelonia mydas. Comp Biochem Physiol [A] 63:127-133

Carpenter CC (1966) The marine iguana of the Galápagos Islands, its behaviour and ecology. Proc Calif Acad Sci 34:329-376

Darwin C (1883) Journal of researches. New Edition. Appleton, New York

Eibl-Eibesfeld I (1964) Amblyrhynchus cristatus (Iguanidae), Nahrungserwerb an Land und unter Wasser. Encyclopaedia Cinematographica, Göttingen

Foley WJ, Bouskila A, Shkolnik A, Choshniak I (1992) Microbial digestion in the herbivorous lizard Uromastyx aegyptius (Agamidae). J Zool (Lond) 226:387-398

Harlow HJ, Hillmann SS, Hoffmann M (1976) The effect of temperature on digestive efficiency in the herbivorous lizard Dipsosaurus dorsalis. J Comp Physiol 111:1-6

Harwood RH (1979) The effect of temperature on the digestive efficiency of three species of lizards, Cnemidophorus tigris, Gerrhonotus multicarinatus and Sceloporus occidentalis. Comp Biochem Physiol [A] 63:417-433

Hobson ES (1965) Observations on diving in the Galapagos marine iguana, Amblyrhynchus cristatus (Bell). Copeia 1965:249-250

Hobson ES (1969) Remarks on aquatic habits of the Galapagos marine iguana, including submergence times, cleaning symbiosis, and the shark threat. Copeia 1969:401-402

Huey RB (1982) Temperature, physiology, and the ecology of reptiles. In: Gans C and Pough FH (eds) Biology of the reptilia, physiology, physiological ecology, vol 12. Academic Press, New York, pp 25-92

Hungate RE (1966) The rumen and its microbes. Academic press, New York

Janis C (1976) The evolutionary strategy of the Equidae, and the origins of rumen and cecal digestion. Evolution 30:757-774

Langer P, Snipes RL (1991) Adaptations of gut structure to function in herbivores. In: Tsuda T, Sasaki Y, Kawashima R (eds) Physiological aspects of digestion and metabolism in ruminants. Academic Press, San Diego, pp 349-384

Laurie WA (1990) population biology of marine iguanas (Amblyrhynchus cristatus). 1. Changes in fecundity related to a population crash. J Anim Ecol 59:515-528

Laurie WA, Drown D (1990a) Population biology of marine iguanas (Amblyrhynchus cristatus). 2. Changes in annual survival rates and the effects of size, sex, age and fecundity in a population crash. J Anim Ecol 59:529-544

Laurie WA, Drown D (1990b) Population biology of marine iguanas (Amblyrhynchus cristatus). 3. Factors affecting survival. J Anim Ecol 59:545-568

McBee RH (1971) Significance of the intestinal microflora in herbivory. Annu Rev Ecol Syst 1:65-176

Nagy KA (1977) Cellulose digestion and nutrient assimilation in Sauromalus obesus, a plant-eating lizard. Copeia 1977:355-362

Nagy KA (1982) Energy requirements of free-living iguanid lizards. In: Burghardt GM, Rand AS (eds) Iguanas of the world: their behavior ecology and conservation. Noyes, Park Ridge, NJ, pp 49-59

Nagy KA, Shoemaker VH (1984) Field energetics and food consumption of the Galapagos marine iguana, Amblyrhynchus cristatus. Physiol Zool 57:281-290

Pough FH (1973) Lizard energetics and diet. Ecology 54:837-844

Trillmich KGK, Trillmich F (1984) The mating system of pinnipeds and marine iguanas: convergent evolution of polygyny. Biol J Linn Soc 21:209-216

Trillmich KGK, Trillmich F (1986) Foraging strategies of the ma* rine iguana, Amblyrhynchus cristatus. Behav Ecol Sociobiol $18: 259-266$

Troyer K (1984a) Behavioural acquisition of the hindgut fermentation system by hatchling Iguana iguana. Behav Ecol Sociobiol 4:189-193

Troyer K (1984b) Diet selection and digestion in Iguana iguana: the importance of age and nutrient requirements. Oecologia 61:201-207 
Troyer K (1984c) Structure and function of the digestive tract of a herbivorous lizard Iguana iguana. Physiol Zool 57: 1-8

Troyer K (1987) Small differences in daytime body temperature affect digestion of natural food in a herbivorous lizard (Iguana iguana). Comp Biochem Physiol [A] 87:623-626

Van Damme R, Bauwens D, Verheyen RF (1991) The thermal dependence of feeding behaviour, food consumption and gutpassage time in the lizard Lacerta vivipara Jacauin. Funct Ecol 5:507-517

Waldschmidt SR, Jones SM, Porter WP (1986) The effect of body temperature and feeding regime on activity, passage time, and digestive coefficient in the lizard Uta stansburiana. Physiol Zool $59: 376-383$
Waldschmidt SR, Jones SM, Porter WP (1987) Reptilia. In: Pandian TJ, Vernberg FJ (eds) Animal energetics. Academic Press, London, pp 553-619

Wikelski M (1991) Foraging ecology of the herbivorous marine iguana (Amblyrhynchus cristatus Bell): an integrated approach. Diploma thesis, University of Munich

Windell JT, Sarokon JA (1976) Rate of gastric evacuation in the lizard, Anolis carolinensis (Sauria: Iguanidae). Herpetologica $32: 18-23$

Zimmermann LC, Tracy CR (1989) Interactions between the environment and ectothermy and herbivory in reptiles. Physiol Zool 62:374 409 